\title{
ENTERING IN THE GLOBAL MANUFACTURING OUTSOURCING MARKET AND INNOVATIVE DEVELOPMENT OF THE UKRAINIAN INDUSTRIAL ENTERPRISES
}

\author{
Kseniia GOROVA1, PhD in Economics, Associate Professor, \\ NTU „Kharkiv Polytechnic Institute”, Ukraine \\ Oleksandr DLUHOPOLSKYI², Habilitation in Economics, Professor, \\ Ternopil National Economic University, Ukraine \\ Tetiana DLUHOPOLSKA ${ }^{3}$, PhD Student, \\ Ternopil National Economic University, Ukraine
}

DOI: https://doi.org/10.36004/nier.es.2019.2-02

JEL Classification: D29, F02, F23, 032

UDC: 005.591.6(477)

\section{ABSTRACT}

The urgency of the research is caused by the problem of innovative development that is acutely facing the Ukrainian industrial enterprises. According to statistics, a rather small share of industrial enterprises innovates in their activities and produces innovative products caused by the lack of investment and experience to intensify innovation. Therefore, enterprises should use modern forms of business organization such as outsourcing that has proved itself as a strategic partnership form and a mechanism for the transfer of innovation. The purpose of the research is to develop recommendations for the release of the Ukrainian industrial enterprises to the global manufacturing outsourcing market to ensure their innovative development. The subjects of the study are the types of manufacturing outsourcing and the mechanism of their impact on the innovative development of enterprises. This article is based on the research results of the Ukrainian and foreign scientists, the information on analytical reports, official statistics and public companies' information. The methods used in the research are analysis and synthesis, theoretical generalization, statistical analysis. The article analyzes the position of Ukraine in the global manufacturing outsourcing market. The prospects of the Ukrainian industrial enterprises to enter the global market of industrial outsourcing have been determined. Recommendations on the choice of type of industrial outsourcing have been developed. The results of the research can be used in the practical activity of industrial enterprises and in further researches in the field of innovation management and enterprise organization.

Keywords: manufacturing outsourcing, industry, enterprise, innovative development, innovation, market.

Relevanța studiului se datorează problemei dezvoltării inovaționale, care este deosebit de acută pentru întreprinderile industriale ucrainene. Conform statisticilor ucrainene, o pondere destul de mică a întreprinderilor industriale introduce inovații în activitățile lor și produce produse inovatoare, din cauza lipsei investițiilor și a experienței pentru intensificarea inovației. Prin urmare, întreprinderile sunt obligate să folosească forme moderne de organizare a afacerilor, de exemplu, externalizarea, care s-a stabilit ca o formă eficientă de parteneriat strategic și un mecanism de transfer al inovației. Scopul cercetării este să elaboreze recomandări privind intrarea întreprinderilor industriale ucrainene pe piaţa mondială de externalizare a producției pentru a asigura dezvoltarea lor inovatoare. Obiectul cercetării îl constituie tipurile de externalizare a producției și mecanismul influenței acestora asupra dezvoltării inovatoare a întreprinderilor. Articolul se bazează pe rezultatele studiilor realizate de cercetători ucraineni și străini, informații din rapoarte analitice, statistici oficiale și informații de la companii publice. Metodele de cercetare utilizate în această lucrare includ analiza și sinteza, generalizarea teoretică și analiza statistică. Articolul analizează poziția Ucrainei pe piața globală de externalizare a producției. Sunt determinate perspectivele întreprinderilor industriale ucrainene de a intra pe piața globală de externalizare industrială. Sunt elaborate recomandări privind selectarea tipurilor de externalizare industrială. Rezultatele cercetării pot fi utilizate în activitățile practice ale întreprinderilor industriale și în cercetarea ulterioară în domeniul managementului inovației și organizarea afacerilor.

Cuvinte-cheie: externalizarea producției, industrie, întreprindere, dezvoltare inovatoare, inovație, piață.

1 C Kseniia GOROVA, $\$ ksenya.gf@gmail.com

2 (C) Oleksandr DLUHOPOLSKYI, dlugopolsky77@gmail.com

3 (C) Tetiana DLUHOPOLSKA, tetianadluhopolska@gmail.com

No. 2 / 2019 
Актуальность исследования обусловлена проблемой инновационного развития, которая особенно остро стоит перед украинскими промышленными предприятиями. Согласно украинской статистике, довольно небольшая доля промышленных предприятий внедряет инновации в свою деятельность и производит инновационные продукты, что обусловлено отсутствием инвестиций и опыта для интенсификации инноваций. Поэтому предприятия вынуждены использовать современные формы организации бизнеса, например, аутсорсинг, который зарекомендовал себя эффективной формой стратегического партнерства и механизмом передачи инноваций. Целью статьи является разработка рекомендаций по выходу украинских промышленных предприятий на мировой рынок производственного аутсорсинга для обеспечения их инновационного развития. Предметом исследования являются виды производственного аутсорсинга и механизм их влияния на инновационное развитие предприятий. Статья основана на результатах исследований украинских и зарубежных ученых, информации аналитических отчетов, официальной статистике и информации от публичных компаний. Методы исследования, использованные в работе, включают анализ и синтез, теоретическое обобщение, статистический анализ. В статье анализируется положение Украины на мировом рынке производственного аутсорсинга. Определены перспективы выхода украинских промышленных предприятий на мировой рынок промышленного аутсорсинга. Разработаны рекомендации по выбору типов промышленного аутсорсинга. Результаты исследования могут быть использованы в практической деятельности промышленных предприятий, а также для дальнейших исследований в области управления инновациями и организации бизнеса.

Ключевые слова: производственный аутсорсинг, промышленность, предприятие, инновационное развитие, инновации, рынок.

INTRODUCTION. The Ukrainian economy is in a crisis now that is caused by the long-term political and economic instability in the country. Industrial enterprises operate in conditions of national currency instability, economic relationships breaking, the loss of sales markets and the lack of sufficient investment resources. Industrial enterprises don't have enough funding for innovative development, improvement of their products and renewal of fixed assets. Due to globalization and the rapid development of scientific and technological progress, competitive advantages are achieved by enterprises that are actively introducing innovations into their activities. At the same time, it's impossible to keep business in competition for those enterprises that don't have any ability to reach the modern technological level. It means that it will be very difficult for the Ukrainian industrial enterprises to get a worthy place in the global market by themselves.

Therefore, they need to use advanced forms of business organization that helps to achieve the industry leaders' level. One of these forms is outsourcing which has proven itself as a way to transfer innovations. The Ukrainian industrial enterprises should consider the possibility of performing separate processes of the production cycle or the entire production process for the world famous brands. It will allow them to get some experience, use advanced technologies and introduce innovations into their work. The Ukrainian industrial enterprises have all the prerequisites for entering the world market of industrial outsourcing. The country has a sufficient amount of educated professional labor resources with practical experience and low wages. Also, there are a lot of industrial enterprises and research organizations with good potential. But they lost their competitiveness due to the lack of funding and obsolescence of the material base. It's necessary to realize that all changes at the national level and at the level of most enterprises can provide the attractiveness of domestic companies for foreign partners.

LITERATURE REVIEW. The globalization trends create a lot of conditions for a further global division of labor and the allocation of countries specializing in the outsourcing for certain services and business processes. It should be noted, that Ukraine has all the chances to take a decent place in the global outsourcing market according to the low cost of labor and significant scientific, technological and intellectual potential. This will increase employment and stimulate the revival and development of individual sectors of the national economy. Also, outsourcing is well known as a way of innervations transfer, so it will help the Ukrainian industrial enterprises in their innovative development.

The analysis of publications of the Ukrainian and foreign scientists has shown the diversity of views on the definition of the outsourcing concept. Supporters of the functional approach in determining the economic essence of outsourcing are [12, HEJVUD, B., 2004; 16, LEMIŠ, K.M.,2010; 25, ZAGORODNIY, A.H., 
PATRYN, H.O., 2009]. According to other scientists [18, MOČERNYJ, S.V. et al., 2005; 22, STRILETZ, V. et al., 2010], outsourcing is a kind of partnership interaction between business entities and it is a way of cooperation. Researchers [7, DOMINGUEZ, L., 2006; 15, KOHAN, V.P., 2013] see the main importance of outsourcing in the possibility of attracting resources from other organizations, especially labor, material, technical, intellectual, etc.

The globalization aspect of outsourcing is considered by Duginec' G.V. [8, 2012]. We can generalize the basic approaches to outsourcing definition:

- functional (outsourcing is the process of transferring individual functions or business processes of the enterprise to external executors on a long-term, paid basis);

- cooperative (outsourcing is a form of business relations based on partnership, where the performer provides and develops certain aspects of its activity in the interests of the customer, while both participants are equally interested in the success of the common cause);

- resource (outsourcing is the use of labor, material, intellectual, technical resources of a third-party organization);

- organizational (outsourcing is a form of business organization the implementation of which is accompanied by the reorganization of the enterprise that may be characterized by optimization of the organizational structure or the separation of the enterprise unit into a separate economic entity or the withdrawal of it and all related assets to the organization of the service provider);

- strategic (outsourcing is an enterprise management strategy that allows focusing on key competencies);

- target (outsourcing is a method of optimization and increase of efficiency of the enterprise activity, increase of competitiveness, increase of economic safety and stability of the enterprise, crisis management, increase of the cost of the enterprise, etc. due to the concentration of efforts on the main activity);

- globalization (outsourcing is an instrument of the globalization of the world economy, a way to include all subjects of world economic relations in the system of global cooperation, which provides for deepening the specialization of individual regions for the implementation of certain business processes for international customers).

It can be argued that outsourcing is a modern form of business organization that promotes the globalization of the international economy and the creation of powerful virtual organizations around a parent company that owns a trademark or brand and provides all other business processes including production to third-party executives who are interested in common success with the customer on a longterm, paid basis in order to ensure the efficiency of the activity, increase the competitiveness and stability of the enterprise as well as its flexible in accordance with current external conditions. Globalization trends create more and more conditions for the further distribution of labor and responsibilities determining the countries specializing in outsourcing of some services and business processes. According to the low labor cost and significant scientific, technological and intellectual potential Ukraine, it has all the chances to take a decent place in the international outsourcing market, which will increase employment and stimulate the revival and development of individual sectors of the national economy.

The development of outsourcing in different countries of the world has been studied by many scientists, including [2, BABANIN, O.S., 2012; 7, DOMINGUEZ, L., 2006] and others. Provided investigations are aimed for determining the role of outsourcing in the modern Ukrainian economy and the possibility of adopting the world experience of its application to domestic realities, market structure of outsourcing services and its main trends.

The major trends in the global outsourcing market based on a number of publications of the consulting firms allow making some conclusions. It was found currently that the Asia-Pacific region is the leader in the supply of outsourcing services. The leaders among the countries are India, China, Vietnam, Philippines and Malaysia. The most successful European providers of outsourcing services are Ireland and Poland. There were investigated the Top 100 Outsourcing Destinations by Tholons agency, Global Outsourcing Index and Future Outsourcing Index developed by Minevich M., Richter F.J. $[17,2015]$, IT Outsourcing Review by CEEOA.

Assessment of attractiveness of the region as an outsourcer should be primarily based on the balance of indicators such as the order of execution risks in the country and its cost. Special attention 
should be paid to the availability of human resources, transport infrastructure, and communications, the overall development of the country. The customer placing orders for manufacture outsourcing will be interested in the quality of manufactured products and low risks. Formation of the country as a successful manufacturing outsourcing will take place if it has industrialized regions, cities-centers of innovation characterized by a large number of industrial enterprises and research institutions; effective public support; developed business environment in the country and its regions.

Unfortunately, Ukraine has not found its place in the outsourcing market yet. The high level of corruption, economic and political instability repel foreign companies from placing outsourcing orders in Ukraine. IT-outsourcing is the only sector in which Ukraine has succeeded. It is done due to the high intellectual potential of national experts and the possibility to develop this activity without significant investment costs. But Ukraine should evolve towards the provision of outsourcing services in other activities. Ukraine could become a powerful manufacturing outsourcer because it has a large number of industrial companies that have production facilities, skilled workers and engineers. The development of manufacturing outsourcing will improve the economic situation of the enterprises and promote the development of the national economy.

METHODOLOGY AND RESEARCH METHODS. It has been considered an important scientific problem such as the search for an effective way to intensify the innovative development of Ukrainian industrial enterprises. This should happen due to their entry into the global market of manufacturing outsourcing. This is a new approach to innovative development as previously scientists have suggested that companies provide it on their own or at the funds of investors but not through a long-term strategic partnership like outsourcing.

In order to ensure the innovative development of the Ukrainian industrial enterprises in the global manufacturing outsourcing market, it is expedient to use the following methods [11, GLUSHAK, N., GLUSHAK, O. et al., 2016]: analysis, that is the division of the object of research, that means the innovative development of the the Ukrainian industrial enterprises at the global manufacturing outsourcing market into its components to improve the knowledge of the process and phenomena being studied; synthesis, which is the combination of difficulties and opportunities of the Ukrainian industrial enterprises into a single whole in order to establish their possibilities for innovation development with the help of manufacturing outsourcing at the global market; theoretical generalization, that helps to make general conclusions and develop some recommendations and show the result of the research for the release of the Ukrainian industrial enterprises to the global market of manufacturing outsourcing to ensure their innovative development; comparison, that is, calculation of the rate of the Ukrainian enterprises' development by the main macroeconomic indicators and determining the dynamics of their changes; statistical analysis, that is used for converting empirical data obtained during the study into the meaningful analysis, hypothesis testing and interpretation; expert evaluation, which enables to describe the qualitative characteristics of the investigated process.

The theoretical basis of the study is the works of scientists on the implementation of outsourcing in the activities of enterprises, data of rating agencies and statistical information. The aim of the article is to develop recommendations for the release of Ukrainian industrial enterprises in the global market of manufacturing outsourcing to ensure their innovative development. For this purpose, the article proposes to investigate how the implementation of outsourcing orders will facilitate the transfer of innovations; identify the main types of industrial outsourcing; determine the criteria by which enterprises should choose a type of outsourcing for supply to customers.

RESULTS. Development of the Ukrainian economy requires new approaches to business organization. Old methods and forms of management can't provide sustainable development. We can estimate an economic situation in Ukraine using international rankings. Ukraine has rank 71 among 190 countries according to one of the most famous rankings Doing Business that characterize ease of business performance in different countries of the world [6, 2019].

Another ranking Global Competitiveness Index gives a rank 83 to Ukraine among 140 countries [10, SCHWAB, K., 2018]. It assesses the microeconomic and macroeconomic foundations of national competitiveness, which is defined as the set of institutions, policies, and factors that determine the level of productivity of a country. According to the similar World Competitiveness Ranking developed by the World Competitiveness Center Ukraine's rank looks worse, it's only 59th 
out of 63 countries $[13,2018]$. This index is an annual study of global competitiveness, assesses and analysis of the countries' ability to create and maintain an environment in which enterprises may effectively compete. We can see that world researchers don't see Ukraine as a competitive, developed and attractive country for doing business. This situation reduces its image as an economic partner in the international arena. It obstructs the establishment of sustainable economic relations and attraction of investments. It's especially reflected in the activities of industrial enterprises due to the deterioration of political relations with some ex-USSR countries, lost regular customers of their products and remained without stable contracts.

The industrial sector of the Ukrainian economy is characterized by a large number of economic entities and has strategic significance for our state providing majority people with their positions. There are 2,386 business entities in the industry in Ukraine. Among them, there are 42,026 enterprises and 81,850 private entrepreneurs. The industry provides the position with 2,334.2 thousand people, but after of the crisis in Ukraine, the number of employees in the industry decreases annually. Using the advice of experts [21, 2019], we can compare this situation with 2011 when industrial enterprises of Ukraine employed $3,031.7$ thousand people. The number of sales in recent years has been stable but increased last year. According to the great inflation, one can say about inhibition of sales. Therefore, one can conclude that there is a deceleration of the development in the industrial sector of Ukraine and the high probability of a largescale crisis in this sector of the economy. Particularly disappointing is the annual decrease in the number of large industrial enterprises which provide a significant number of position and a major share of output.

Successful operation of industrial enterprises must be supported by the high-quality personnel which has professional knowledge and skills inclined to innovate and have intellectual, scientific and technical potential. Unfortunately, industrial enterprises cannot provide sufficient wages. Using official statistics [21, 2019], we can see that the average wages in the industry are UAH 10,236 per month. It hasn't promoted the attraction of highly skilled personnel in this area recently. Lack of interest to the enterprises' results and high-skilled personnel inflows causes lack of innovation development and improvement of labor efficiency. The efficiency of industrial enterprises depends on the availability and conditions of the necessary fixed assets. Wear factor is $58 \%$ now, that could lead to a technical crisis at the industrial enterprises. The renovation of fixed assets at industrial enterprises requires significant investments.

Also, we can see the low innovative activity of industrial enterprises. Only $14,3 \%$ of industrial enterprises implemented innovations in 2017 [21, 2019]. 1,831 new technological processes were implemented, including 748 low-consumption and resource-saving ones, and the launch of 2,387 items of innovative products, including 751 new types of equipment this year. However, the share of implemented innovative products in the volume of industrial goods is still a fairly low share, only $0,7 \%$. And, as it has been proved by official statistic information [21, 2019], since 2000 this indicator has decreased almost 10 times. This suggests the backlog of domestic industrial enterprises from the global scientific and technological progress and their low attention to the introduction of the latest technological advancements in the production and updating of products. This can lead to a technological crisis at the industrial enterprises. There is a negative trend of decreasing investments in innovation development. The total amount of costs for innovation activity was UAH 9,117.5 in 2017 $[21,2019]$. To compare with 2016, these costs were UAH 23,229.5 in 2016. The largest amount of money - UAH 5,898.8 - was spent on the purchase of machines, equipment, and software [21, 2019]. The main source of financing remains in the own funds of enterprises is not enough to update the innovative potential of Ukrainian industry under current conditions. The World Intellectual Property Organization, Cornell University, and the Insead international business school annually calculate the Global Innovation Index that takes into account such indicators as human capital, development of education, business environment, availability of intangible assets and number of intellectual workers. According to the Global Innovation Index [23, DUTTA, S., et al., 2018], Ukraine has rank 43 among 126 countries of the world. This rank is very low taking into account a great number of industrial enterprises, research organizations, and universities situated in Ukraine.

On the basis of the analysis, it is possible to make some conclusions about the high probability of crisis phenomena at industrial enterprises. The deterioration of the financial activity of enterprises has an impact on the development of the financial crisis. It is accompanied by reduction insolvency and the possibility of 
attracting investment resources that are necessary for enterprises. Lack of labor resources and low wages can lead to a reduction in labor productivity and employee interests in companies' development that could indicate the organizational crisis. Violations of economic relationships, the absence of new supply channels and markets can lead to a sales crisis. Therefore, talking about the innovative development of domestic industrial enterprises one can say that it's very difficult today because it requires significant financial infusions. It will be almost impossible for the enterprises to get out of a crisis and restore their innovative potential by themselves, therefore, it is necessary to seek help from the third parties.

Considering outsourcing as a way of industrial enterprises innovation development it's necessary to pay more attention to the concept of innovation. Innovations are newly created and improved competitive technologies, products or services, as well as organizational and technical decisions of an industrial, administrative, commercial or other nature that significantly improve the structure and quality of production and the social sphere. Objects of innovation activity are: innovative programs and projects; new knowledge and intelligent products; production equipment and processes; infrastructure of production and entrepreneurship; organizational and technical decisions of an industrial, administrative, commercial or other nature that significantly improve the structure and quality of production and social sphere; raw materials, means of their extraction and processing; commodity products; mechanism of formation the consumer market and marketing of commodity products. Innovative development is based on the continuous search and use of new ways and areas of realizing the potential of the enterprise in changing environmental conditions within the framework of the chosen mission and the accepted motivation of activities related to the modification of existing and the formation of new markets. Innovation activity is aimed at the use and commercialization of the results of research and development and promotes the launch of new competitive products and services on the market. As it was mentioned, it would be very difficult for Ukrainian industrial enterprises to provide innovation development on their own. Therefore, it's necessary to get long-term business agreements with leaders of scientific and technological progress. Ukrainian enterprises can offer to their partners themselves as industrial outsourcers. Foreign companies will be able to reduce the cost of the production process due to its partial or full implementation in Ukraine, and Ukrainian enterprises will receive experience, investment, technology, personnel training, etc.

The customer of outsourcing services has financial, material and intellectual resources. By concluding a long-term contract for transferring part or the entire production process to an outsourcer in additional to the order he transfers his intellectual capital first of all. As a result, the outsourcer makes an innovative breakthrough in introducing technological, product, organizational, process and other innovations. In addition, if the customer is interested in a long-term partnership, he can become an investor in the outsourcer, help him with the organization of logistics and staff training. There are good preconditions for the entry of Ukrainian industrial enterprises in the global outsourcing market. Most machine-building enterprises or research institutions in Ukraine were created in USSR times. Almost all of them were not economic entities with a closed cycle of production but engaged in the development and production of individual parts and units. The final product was the result of the work of a large number of enterprises located in different parts of the former USSR. For example, the Kharkiv machine-building plant "FED" produced hydraulic, fuel and electric systems for aviation engineering. Some units were supplied to the "Rubin" plant located in the Moscow region. "Rubin" manufactured runways, hydro units and hydro systems for airplanes and other aircraft. Its products were supplied to aviation and helicopter factories of the USSR, located in Voronezh, Kaliningrad, Kyiv, Lviv and other cities, and back in Kharkiv - to the Kharkiv Aviation Plant. Aircraft design was provided by separate organizations: Antonov (Kyiv), Tupolev (Moscow), Mikoyan (Moscow), Sukhoi (Moscow). Also the production of FED plant was supplied to the Motor Sich plant, which produced engines for airplanes and helicopters for all aircraft and helicopters factories throughout the USSR.

We can say that domestic industrial enterprises were created as production outsourcers, or endproducers, which transferred part of the production cycle for outsourcing to other enterprises of the USSR. The economic ties created at that time remained until 2014. However, at the moment, with the violation of diplomatic relations with Russia and the inability to interact in the defense industry and scientific and technical cooperation, Ukrainian enterprises were in a situation where the final products themselves can't produce, and the production chain of several enterprises is broken. Therefore, today the way out of this 
situation is possible only through the search for customers to perform part of production processes from Europe and Asia and the establishment of new economic ties.

Today manufacturing outsourcing is an opportunity for economic recovery and innovation development of Ukraine. There are several directions of the possible way to the global market of manufacturing outsourcing for Ukrainian enterprises (fig. 1). We can define four types of manufacturing outsourcing, such as research and development outsourcing, certain parts of the production process outsourcing, assembly operations outsourcing and full manufacturing outsourcing. Ukrainian industrial enterprises could be competitive in the global outsourcing market if they chose the most suitable type of outsourcing to offer to customer. We highlight preconditions of use of each type of manufacturing outsourcing and possible difficulties that the enterprise may face. Also, we provide some examples of successful providing of outsourcing services below to customer.

There is a considerable number of scientific research institutes in Ukraine since the times of the USSR. They may become competitive in the outsourcing market of research and development activities. The specifics of such institutions still remain wide. There is Institute of Mono Crystals, Institute of Mechanical Engineering of the National Academy of Sciences of Ukraine, O.Y. Usikov Institute for Radiophysics and Electronics, National Science Center "Kharkiv Institute of Physics and Technology", Kharkiv Scientific Research and Design Institute "Energoproekt", Institute of Radio Astronomy of the National Academy of Sciences of Ukraine, etc. in Kharkiv (Ukraine). However, not all of them, unfortunately, have sustained economic ties, commercialization of their developments and participation in international production outsourcing projects. A successful example is a project of creating a space system for global monitoring of the dynamic processes in the Earth's ionosphere, as part of the European GMES program, the space weather program SW and the global GEOSS system. The main executor of the project in Ukraine is Space Research Institute National Academy of Sciences of Ukraine. Also we can mention the implementation of the Sea Launch project by the International Company. Launch vehicle Zenit developed by the Design office Yuzhnoye and manufactured at the Production Association Yuzhny Machine-Building Plant named after A.M. Makarov was used as part of the floating missile and space complex. 36 launches of Zenit-3SL launch vehicles with spacecraft for telecommunication purposes were established on the naval platform from April 1999 to December 2014 [5, 2019]. This project is an example of Ukrainian enterprises' action as outsourcers at research and development work, as well as parts of the production process. Unfortunately, the participation of Ukrainian research institutes in such projects is not a widespread practice. It's necessary to provide the training of Ukrainian scientists in internships in innovative world countries and the development of international scientific and technical cooperation.

It is advisable to carry out certain parts of the production outsourcing process for enterprises that have sufficient production capacity and qualified personnel, but don't have a closed production cycle or their final products are uncompetitive but individual nodes, aggregates or production processes are executed at a high level. Such enterprises are the majority of the machine-building enterprises of the former USSR. The powerful enterprise of defense complex State Enterprise "Malyshev Plant" produced diesel engines 6TD-2 for the upgraded version of Al-Khalid tank, which was developed by the Chinese company Norinco and Pakistani Heavy Industries. The tank was manufactured almost entirely on the production facilities of Pakistan except for the engine as Ukraine is capable of manufacturing one of the most reliable models of tank engines working in a hot climate. The Ukrainian engines are also popular for airplanes. A well-known manufacturer of engines for airplanes and helicopters Motor Sich produced engines for Ukrainian and Russian enterprises for a long time. However, due to the political situation in Ukraine the company finds new markets. Motor Sich and the South African company Paramount Group signed a memorandum of cooperation on the joint modernization of military helicopters Mi-24 Super Hind. Companies will explore the possibility of technology exchange. Also, Paramount Group is interested in expanding its cooperation with Ukraine in the production and repair the helicopter engines. In its turn, Motor Sich is extremely interested in technologies related to the production of composite blades for helicopter screws. At the same time, Motor Sich actively cooperates with China providing aircraft engines AI-222K-25, AI-222K-25F and component parts for an L-15 aircraft. The company manufactures, tests, maintains and repairs 55 types and engine modifications for 61 types of aircraft and helicopters of different purposes, operated in 109 countries of the world now [20, 2019]. 


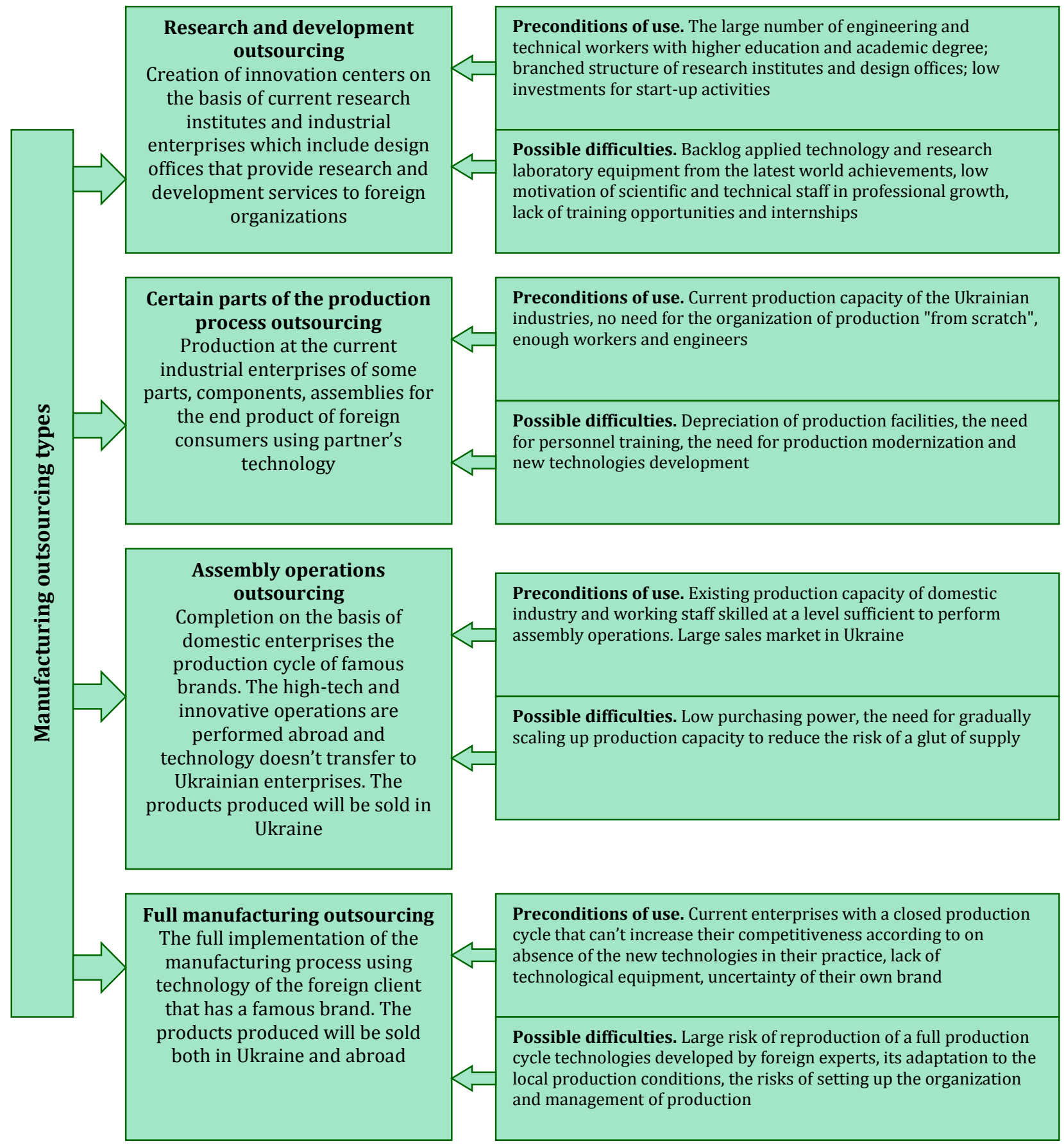

Figure 1. Involvement of the Ukrainian industrial enterprises as manufacture outsourcers Source: Made by authors.

Assembly outsourcing operations that is the final stage of the production process is appropriate for enterprises located near the market of products. It's relevant for products which importation into Ukraine is inconvenient and economically inappropriate given the heavy transportation and significant customs duties. Cars are the kind of such products. As an example, one can mention the production of the Czech brand "Skoda" cars at the Ukrainian company Eurocar. Eurocar is the official producer of VW Group cars in Ukraine that is part of the Atoll Holding group of companies. The plant was opened in December 2001. Eurocar produces the whole range of the brand "Skoda" cars at the moment. The enterprise carries out full-scale production of cars, which includes such major production processes as welding, painting, and assembly of automobiles. The production capacities 
of the plant allow to produce up 100 thousand cars per year and give an opportunity to increase the level of localization of cars produced with the prospect of export development. Welding and dyeing are carried out by the equipment of such well-known companies as Transsystem (Poland), Chropynska Strojirna (Czech Republic), EISENMANN (Germany) [9, 2019]. Creating such a production plant is relatively simple since production capacity is only needed to complete the production process such as welding, painting, and installation. The main preliminary work on manufacturing units and assemblies is carried out at the enterprises of the Czech Republic and Slovakia. This project is of great importance for the development of such Ukraine's scientific and technical potential as technologies are being transferred along with production to the enterprise that will help to improve the skills of Ukrainian specialists.

Provision of full outsourcing services is possible for enterprises that have all the necessary resources to carry out the entire production cycle or the major part of it and don't produce their own products because of its non-competitiveness or no known on the market. In this case, it is more appropriate to take orders for the production of branded products by the technology of the original manufacturer. This may include the possibility of upgrading production capacities, mastering the latest proven technologies and upgrading staff skills. The complete production process for outsourcing was transferred by Daewoo Motors to AvtoZAZ. Daewoo Motors acted as an investor of AvtoZAZ. In 1998 it was invested \$150 million in its authorized capital. In addition to investments Daewoo Motors has provided new technologies, unique quality control systems and own engineering developments. Due to this action there was provided a renovation of production, buildings, energy supply systems, engineering structures and networks at factories in Zaporizhzhya, Melitopol, Chernomorsk, organized quality control of products according to the world standards; the production of Tavriya Nova was restored after modernization at the main plant in Zaporizhzhya; administrative personnel policy was changed. The restoration of the enterprise and bringing its technological base to the world standards was a contribution to the further attraction of new investments as a result of cooperation with Daimler Chrysler, General Motors, Opel, Renault, etc. The result of this cooperation was the mass production of well-known cars in Ukraine: Daewoo Lanos, Daewoo Sens, Chevrolet Aveo $[1,2019]$. This example shows how an enterprise that produces uncompetitive products and owns an unremarkable brand decides to renounce its own name and manufacture cars of other well-known brand and became a leader in the automotive industry in Ukraine for decades.

The Ukrainian industrial enterprises have a lot of opportunities to enter the global outsourcing market successfully. The provision of outsourcing services helps to attract foreign investments and technologies. Successful outsource enterprises may become leading producers of their industry, create their own brands, begin to produce products focused both on the domestic market and delivered to export. Participation in international outsourcing agreements has national importance due to creating new jobs, growth workers' welfare, the inflow of foreign currency funds from abroad. Also, the outsourcing should be mentioned as an instrument of transfer of technologies and the activation of innovation activity of industrial enterprises.

We can see how to choose of the type of manufacturing outsourcing and ways of innovative development depending on characteristics of the enterprises in fig. 2. Industrial enterprises can intensify their innovative activities by obtaining outsourcing orders from high technology enterprises. We can see that enterprises that have closed production cycle and well-known brand should produce goods under their own brand. In this case, their innovation development will be provided by their own resources. But for enterprises not known on the market, this way isn't available. They have to manufacture products of famous brands at their production facilities to provide themselves with orders. But the customer transfers his intellectual capital to the outsourcer in addition to his order. Innovative development, in this case, is provided by transferring the technological process, personnel training, re-equipment of production facilities. Industrial enterprises that could provide only some parts of the manufacturing cycle may be competitive in other types of outsourcing. Some of them that have significant scientific and technical potential should provide services of research and development outsourcing. In this case, Innovative development is provided by scientific and technical cooperation, exchange of experience, assistance in equipping laboratories, research bases. If the enterprise has only manufacturing potential, it could provide 
services of certain parts of the production process outsourcing. But if it located next to the market of products it is advisable to offer services of assembly operations outsourcing. Innovative development will be provided by sharing experience, development of new technologies, re-equipment of production facilities and staff development.

We conducted a study of choice the type of manufacturing outsourcing for some Ukrainian industrial enterprises. We used data of official websites of enterprises and the results of the survey of employees of enterprises. The results of the study are in table 1. Each indicator was evaluated on a scale from one to five.

Table 1

The choice of the type of manufacturing outsourcing of Ukrainian industrial enterprises

\begin{tabular}{|l|c|c|c|c|c|}
\hline \multicolumn{1}{|c|}{ Enterprise } & $\begin{array}{c}\text { Ability to carry } \\
\text { out a closed } \\
\text { production cycle }\end{array}$ & $\begin{array}{c}\text { Well-known } \\
\text { brand in the } \\
\text { market }\end{array}$ & $\begin{array}{c}\text { Significant } \\
\text { scientific and } \\
\text { technical } \\
\text { potential }\end{array}$ & $\begin{array}{c}\text { Location next } \\
\text { to the } \\
\text { market of } \\
\text { products }\end{array}$ & $\begin{array}{c}\text { Recommended type } \\
\text { of manufacturing } \\
\text { outsourcing }\end{array}$ \\
\hline $\begin{array}{l}\text { XTZ (Kharkiv } \\
\text { Tractor Plant) }\end{array}$ & 5 & 4 & 4 & 4 & $\begin{array}{c}\text { Production under its } \\
\text { own brand }\end{array}$ \\
\hline $\begin{array}{l}\text { Kharkiv Aviation } \\
\text { Plant }\end{array}$ & 2 & 4 & 5 & 3 & $\begin{array}{c}\text { Research and } \\
\text { development } \\
\text { outsourcing }\end{array}$ \\
\hline $\begin{array}{l}\text { Tinyakova } \\
\text { Garment Factory }\end{array}$ & 5 & 1 & 3 & 3 & $\begin{array}{c}\text { Full manufacturing } \\
\text { outsourcing }\end{array}$ \\
\hline Eurocar & 1 & 1 & 3 & 5 & $\begin{array}{c}\text { Assembly operations } \\
\text { outsourcing }\end{array}$ \\
\hline Malyshev Plant & 3 & 2 & 3 & 3 & $\begin{array}{c}\text { Certain parts of the } \\
\text { production process } \\
\text { outsourcing }\end{array}$ \\
\hline
\end{tabular}

Source: Made by authors based on [1, 2019; 9, 2019; 20, 2019].

The analysis provided in table 1 helps industrial enterprises to choose the recommended type of manufacturing outsourcing that makes the company occupy a competitive position in the global market for manufacturing outsourcing.

CONCLUSIONS. The main idea of the article is that for the Ukrainian industrial enterprises one of the most effective ways of innovation development is to active offer of their services in the global manufacturing outsourcing market. Ukraine has a good chance to become a successful outsourcing country according to high intellectual and personal potential, the existing material base and the low cost of services offered. Outsourcing contracts will help to attract investment in industrial development, provide an exchange of experience and technology with leading world countries. Ukrainian industrial enterprises can offer foreign customers research and development outsourcing, certain parts of the manufacturing process outsourcing, assembly operations outsourcing and full manufacturing outsourcing.

The scientific result of the study is the development of recommendations on the choice of type of manufactural outsourcing that is advisable for Ukrainian industrial enterprises to enter the global industrial outsourcing market. Enterprises need to assess the strength of their own brand, the ability to implement a closed production cycle on their own production facilities, their scientific and technological potential and proximity to markets to choose a type of outsourcing.

The results of the research can be used by industrial enterprises in strategic management, business organization forms selection and outsourcing contracts. The results can be also used to develop a methodology for assessing the attractiveness of industrial enterprises as manufactural outsourcer in the future. 


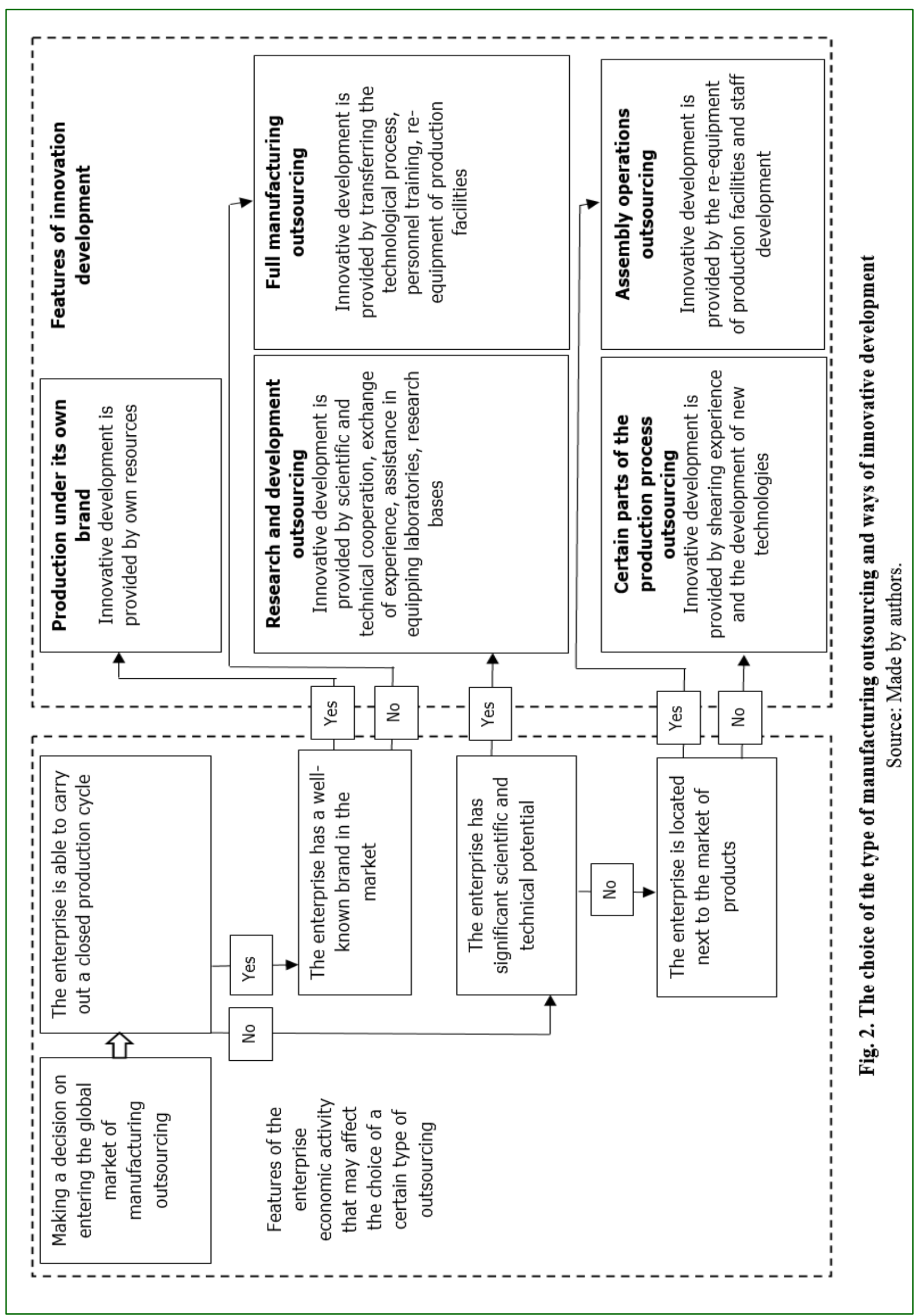

No. 2 / 2019 


\section{REFERENCES}

1. AvtoZAZ company. 2019. [Accesat 23.05.2019]. Disponibil: http://www.avtozaz.com

2. BABANIN, O.S. Ekonomična spivpracâ Ukraïni i SŠA: IT-sektor. In: Zovnišnâ Torgivlâ: ekonomika, finansi, pravo. Kï̈v, 2012, № 5, ss. 27-32. ISSN 2616-6100.

3. Competitiveness Rankings. World Economic Forum. 2018. [Accesat 11.10.2019]. Disponibil: http://reports.weforum.org/global-competitiveness-report-2018/competitiveness-rankings

4. IMD World Competitiveness Online. 2018. [Accesat 26.08.2019]. Disponibil: https://worldcompetitiveness.imd.org

5. Design Office Yuzhnoye. 2019. [Accesat 12.10.2019]. Disponibil: https://www.yuzhnoye.com/en/home

6. Doing Business. 2019. [Accesat 17.05.2019]. Disponibil: http://www.doingbusiness.org/en/rankings

7. DOMINGUEZ, L. The manager's step-by-step guide to outsourcing. New York: Megraw-Hill, 2006. 226 p. ISBN 9780071458245.

8. DUGINEC', G.V. Vpliv Mižnarodnogo autsorsingu na rozvitok lûds'kogo kapitalu v umovah globalizaciï. V: Problemy i perspektivy razvitiâ sotrudničestva meždu stranami Ûgo-Vostočnoj Evropy v ramkah ČĖS i GUAM. Albena-Doneck, 2012, ss. 124-128. ISSN 1990-9187.

9. O0O EvroKar. 2019. [Accesat 23.05.2019]. Disponibil: https://ru.skoda-auto.ua/company/about

10. SCHWAB, K. The Global Competitiveness Index: insight report. 2018. [Accesat 17.08.2019]. Disponibil: http://www3.weforum.org/docs/GCR2018/05FullReport/TheGlobalCompetitivenessReport2018.pdf

11. GLUSHAK, N., GLUSHAK, O. et al. Innovative methods of industrial enterprises management based on the universal network model. 2016. [Accesat 17.09.2019]. Disponibil: https://www.shsconferences.org/articles/shsconf/pdf/2016/06/shsconf_rptss2016_01041.pdf

12. HEJVUD, B. Autsorsing: v poiskah konkurentnyh preimuŝestv. Moskva: Vil'âms, 2004. 176 s. ISBN 58459-0398-X.

13. IMD World Competitiveness Rankings. 2018. Disponibil: https://www.imd.org/globalassets/wcc/docs/release-2018/ranking2018.pdf

14. IT Outsourcing News from Central and Eastern Europe. 2017. [Accesat 23.05.2019]. Disponibil: http://itonews.eu

15. KOHAN, V.P. Autsorsing i dogovori, ŝo jogo oposeredkovuût'. V: Дepžavne budivnictvo тa misceve samovrâduvannâ. 2013, vip. 26, ss. 159-174. ISSN 1993-0941.

16. LEMIŠ, K.M. Metodika prijnâttâ rišen' z vikoristtannâ autsorsingovih tehnologij. V: Naukovi Praci Nacional'nogo Universitetu Harčovih Tehnologij. 2010, № 34, ss. 61-63. ISSN 2617-1945.

17. MINEVICH, M.D., RICHTER, F.J. The Global Outsourcing Report. Opportunities, Costs and Risks. 2015. [Accesat 11.08.2019]. Disponibil: https://www.markminevich.com/pdf/WB_FINAL.PDF

18. MOČERNYJ, S.V., LARINA, Y.S., USTENKO, O.A., ÛRIJ, S.I. Ekonomičnyj enciklopedičnyj slovnik: u 2-h tomah. Tom 1. Lviv, 2005. 616 s. ISBN 966-603-425-5.

19. Tholons Releases 2018 Services Globalization Index - Digital at Scale. [Accesat 23.05.2019]. Disponibil: http://www.digitaljournal.com/pr/3969690

20. State Enterprise "Malyshev Plant" military and civilian technology. 2019. [Accesat 23.05.2019]. Disponibil: https://www.malyshevplant.com/en

21. State Statistics Service of Ukraine (2017-2019). [Accesat 27.10.2019]. Disponibil: https://ukrstat.org/en/menu/publikac_e.htm

22. STRILETZ, V., KARCHYLOVA, N, SAPRYKINA, N. Efficiency of using outsourcing on railway transport and methods of its estimation. In: Economics and Management Journal. 2010, vol. 15, pp. 102-110.

23. DUTTA, S., LANVIN, B., WUNSCH-VINCENT, S. The Global Innovation Index. Energizing the world with innovation. 2018. [Accesat 11.07.2019]. Disponibil: https://www.globalinnovationindex.org/userfiles/file/reportpdf/gii_2018-report-new.pdf

24. Top 50 Emerging Global Outsourcing Destinations 2009. [Accesat 23.05.2019]. Disponibil: http://www.tholons.com/top50.html

25. ZAGORODNIY, A.H., PATRYN, H.O. Autsorcing and its impact on the cost of enterprise. In: Finance of Ukraine. 2009, vol. 9 (166), pp. 87-97. ISSN 2305-7645.

\section{ARTICLE HISTORY}

Received 09 September 2019

Accepted 24 September 2019 